Contributions:

A Study design/planning

B Data collection/entry

C Data analysis/statistics

D Data interpretation

E Preparation of manuscript

$F$ Literature analysis/search

$G$ Funds collection

\title{
AN ADHESIVE BONE CONDUCTION SYSTEM, ADHEAR, A NEW TREATMENT OPTION FOR CONDUCTIVE HEARING LOSSES
}

\section{Patrik WesterkullABCEFG}

Otorix Research and Development, Gothenburg, Sweden

Corresponding author: Patrik Westerkull, Otorix, Ekonomiv 4, 43633 Askim, Sweden, Email: pw@otorix.com, Phone: +46708733707

\begin{abstract}
The adhesive bone conduction concept described here is a completely new type of non-surgical bone conductor. It is based on a disposable adhesive adapter, to which an ear-level audio processor can be connected and disconnected without removing the adhesive adapter positioned on the skin behind the ear. The device, called Adhear, is worn without any pressure against the skin and does not require any bulky retention arrangements, and therefore offers a comfortable and aesthetic solution. Adhear has been reported to offer high patient satisfaction, excellent skin acceptance, and an audiological stimulation comparable to that of a softband or headband arrangement. The adhesive adapters are usually worn for 3 to 7 days before changing to a new one and the adapters can also be worn when sleeping or taking a shower. Adhear offers a new user-friendly, non-surgical bone conduction stimulator suitable for bilateral or unilateral conductive hearing losses and possibly also for SSD.
\end{abstract}

Keywords: bone conduction $\bullet$ adhesive bone conduction $\bullet$ Adhear $\bullet$ conductive hearing loss $\bullet$ bone conduction hearing aid

\section{SISTEMA ADHESIVO DE CONDUCCIÓN ÓSEA ADHEAR. NUEVO MÉTODO DE TRATAMIENTO DE LA PÉRDIDA AUDITIVA CONDUCTIVA}

\section{Resumen}

El dispositivo adhesivo de conducción ósea es un tipo completamente nuevo de conductor óseo no quirúrgico. Está basado en un adaptador adhesivo desechable, al que se puede conectar y desconectar el procesador de sonido a la altura del oído, sin que sea necesario eliminar en cada momento el adaptador adhesivo adherido a la piel detrás de la oreja. El dispositivo no aprieta la piel ni requiere los incómodos conjuntos de sujeción, por lo cual constituye una solución cómoda y estética. El nuevo dispositivo de conducción ósea, no implantable, le garantiza al paciente un alto nivel de satisfacción, una perfecta adaptación a la piel y una estimulación audiológica comparable a las soluciones en las que se utilizan cintas blandas y cintas para audífonos. Los adaptadores adhesivos se utilizan por lo general de 3 a 7 días y luego se cambian por unos nuevos. Pueden ser utilizados durante el sueño o en la ducha. El dispositivo adhesivo de conducción ósea ofrece un método nuevo de estimulación de conducción ósea, de fácil uso y no quirúrgico, adecuado para pacientes con pérdida auditiva unilateral y bilateral tipo conductivo y con sordera unilateral.

Palabras clave: conducción ósea $\bullet$ dispositivo adhesivo de conducción ósea $\bullet$ ADHEAR $\bullet$ pérdida auditiva conductiva $\bullet$ audífono de conducción ósea

\section{СИСТЕМА КОСТНОЙ ПРОВОДИМОСТИ АDНЕАR. НОВЫЙ МЕТОД ЛЕЧЕНИЯ ТУГОУХОСТИ КОНДУКТИВНОГО ТИПА}

\begin{abstract}
Абстракт
Аппарат костной проводимости - это совершенно новый вид нехирургического костного проводника. Он опирается на одноразовом клейком адаптере, к которому можно подключать и отключать аудиопроцессор на уровне уха, без необходимости каждый раз удалять клейкий адаптер, приклеенный на кожу за ухом. Аппарат не давит на кожу, не требует использования неудобных поддерживающих комплектов, благодаря чему является удобным и эстетичным решением. Новое устройство костной проводимости, не требующее хирургического вмешательства, обеспечивает пациентам высокий уровень удовлетворения, прекрасную адаптацию на коже и аудиологическую стимуляцию, сравнимую с решениями, использующими мягкие головные ленты и ленты для слуховых аппаратов. Клейкие адаптеры носятся обычно в течение 3 - 7 дней, а потом меняются на новые. Их можно использовать во время сна или приёма душа. Клейкое устройство костной проводимости предлагает новый, удобный для пользователя и нехирургический метод стимуляции костной проводимости, который подойдёт пациентам с односторонней и двусторонней тугоухостью кондуктивного типа, а также с односторонней глухотой.
\end{abstract}

Ключевые слова: костная проводимость • клейкое устройство костной проводимости • ADHEAR • кондуктивная тугоухость - слуховой аппарат на костную проводимость 


\title{
ADHEZYJNY SYSTEM PRZEWODNICTWA KOSTNEGO ADHEAR. NOWA METODA LECZENIA UBYTKÓW SŁUCHU TYPU PRZEWODZENIOWEGO
}

\begin{abstract}
Streszczenie
Adhezyjne urządzenie przewodnictwa kostnego to zupełnie nowy rodzaj niechirurgicznego przewodnika kostnego. Jest oparty na jednorazowym przyczepianym adapterze, do którego można podłączać i odłączać procesor dźwiękowy na wysokości ucha, bez konieczności każdorazowego usuwania adhezyjnego adaptera przyczepionego do skóry za uchem. Urządzenie nie naciska na skórę oraz nie wymaga nieporęcznych zestawów podtrzymujących, przez co stanowi wygodne i estetyczne rozwiązanie. Nowe niewszczepialne urządzenie przewodnictwa kostnego zapewnia pacjentom wysoki poziom satysfakcji, doskonałą adaptację do skóry oraz stymulację audiologiczną porównywalną z rozwiązaniami wykorzystującymi miękkie opaski i opaski do aparatów słuchowych. Adhezyjne adaptery stosuje się zwykle przez 3 do 7 dni, a następnie zmienia się je na nowe. Mogą być stosowane podczas snu lub pod prysznicem. Adhezyjne urządzenie przewodnictwa kostnego oferuje nową, przyjazną użytkownikom i niechirurgiczną metodę stymulacji przewodnictwa kostnego, odpowiednią dla pacjentów z jednostronnym i obustronnym ubytkiem słuchu typu przewodzeniowego oraz jednostronną głuchotą.
\end{abstract}

Słowa kluczowe: przewodnictwo kostne • adhezyjne urządzenie przewodnictwa kostnego • ADHEAR • ubytek słuchu typu przewodzeniowego • aparat słuchowy na przewodnictwo kostne

\section{Introduction}

There is a need for a well-functioning, non-surgical bone conduction device for bilateral and unilateral conductive hearing losses and possibly also for SSD.

The drawbacks of existing bone conductors - retained by a steel-spring headband, spectacles, or an elastic softband - are well known to anyone with experience of conventional bone conductors. Poor comfort due to the constant pressure and poor aesthetics from the required retention arrangements are among the most widely noted weaknesses (1). These non-surgical bone conduction solutions are, however, still available and used by patients around the world.

Numerous attempts have been made to find better and more acceptable solutions to the bone conduction design challenges. Throughout the last decades, significant innovative efforts and investments have been made in order to find ways of avoiding bulky and uncomfortable retention solutions. However, only concepts requiring implant surgery have been able to address the drawbacks with conventional bone conductors, which have led to other challenges and limitations.

The previous bone conduction development efforts described here do not cover all aspects and details of bone conduction technologies and their history. However, it should offer a valuable background to the need for an improved non-surgical bone conductor and the development of the Adhear adhesive bone conductor.

\section{The percutaneous direct bone conductor}

At the beginning of 1977, the idea of a percutaneous boneanchored hearing aid (Baha) came to Prof. Olle Hallén at Sahlgren hospital in Gothenburg, Sweden (Prof. Stig Arlinger, pers. comm.), and later the same year the first Baha implantations were performed (2). This direct bone-conduction principle offered an efficient and powerful boneconduction solution (3). The further advantages of this concept were that it offered safe retention without any constant pressure against the skin and that no bulky headband arrangements were required. The system offered a way for the device's vibrator to have direct, firm mechanical access to the bone of the skull without any damping though the skin. The compromise was, of course, that the concept required surgery and permanent skin penetration. In the late '90s and early '00s, researchers and leading clinics further investigated the clinical possibilities of bone conduction. The benefits for patients with unilateral conductive losses (4), single-sided deafness (SSD) (5), as well as the benefits of bilateral fitting (6), were investigated and further clinical applications emerged. This clinical research was facilitated by the fact that, for the first time, clinics had access to, and experience with, a wellfunctioning ear-level bone conduction device. The clinical and technical research and developments of Baha during this period are summarized by Westerkull (7). The hearing division of Nobel Biocare, who established the percutaneous Baha product on the market (including FDA approval in 1996), was spun off into a dedicated company, Entific Medical Systems, in 1999. Entific and the Baha system were acquired by Cochlear Corp. in 2005.

Aside from the Baha system, the percutaneous concept has since been further developed and, in 2004, the author founded the independent R\&D company Otorix for the development of a new percutaneous bone conduction system with newly developed skin penetration and audio processor coupling (8). A few years later, this new system was acquired by Oticon A/S and further developed in Oticon Medical. In 2009, the new system was introduced on the market under the name Ponto System.

Although the percutaneous concept has been a success and the technology and surgical procedures have been improved, the introduction of surgery and implant technology added increased complexity to bone conduction treatment, given that aspects - such as wearing a permanent implant, surgical planning, anesthesia, medical considerations, and additional costs - now had to be considered. The percutaneous bone-anchored hearing aid is a well-established clinical treatment, although the method of skin penetration may vary depending on surgical preparation and the patient's personal hygiene (3).

\section{The softband for a bone-anchored audio processor}

For some patients, however, surgical treatment is not an option, so that in 2001 the Baha Softband was introduced to offer improved retention compared to steel-spring headbands, especially for small children (9). A bone-anchored 
hearing device connected to a softband is currently a welldocumented treatment for small children who are unsuited for implant surgery, and it is also the most common arrangement to preoperatively evaluate candidates for implantation. Audiologically, a softband is a successful treatment for conductive hearing losses (10); however, from a comfort and cosmetic point of view, a softband solution is not popular among children (11).

\section{Magnetically attached bone conductor with ex- ternal vibrator}

To overcome the cosmetic drawbacks of a headband or softband solution, a partially implanted magnetically retained bone conductor without skin penetration, named Sophono, was introduced by Prof. Ralf Siegert in 2006 (12). It has a magnetic implant under the skin, and the external audio processor with the vibrator is magnetically retained. The advantage of this concept is that no headband arrangement is required. The vibrations are damped through the skin in a similar manner to a conventional bone conductor. Therefore, in spite of implant surgery, the output and audiological performance are more in the range of a nonsurgical concept and it cannot compete with a direct bone conductor such as a percutaneous device (13). Since the audio processor includes the weight of both the vibrator and magnet, retention may also be a challenge (14). Magnetically retained devices may fall off too easily if the retention force is too weak, while if it is too strong it may cause pain and discomfort, and this trade-off becomes a challenge with increasing device weight. Sophono Inc. was acquired by Medtronic in 2015.

A further development of this type of concept is now represented on the market by the Baha Attract device introduced in 2013 by Cochlear Corp. (15). The Baha Attract includes some additional features and the magnetic attachment of the audio processor also includes a soft pad that is used to distribute pressure over the area of skin contact to improve skin tolerance.

\section{Semi-implantable, active, direct bone conductor with implanted vibrator}

The latest addition to implant-based bone conduction concepts is the Bonebridge, introduced by Med-El in 2012 (16). This concept has an implanted vibrator, usually positioned in the mastoid, so the vibrator is in direct connection with the bone of the skull, thus offering similar high acoustic performance to a percutaneous system (17). A significant advantage is that there is no skin penetration, since the signal to the vibrator is transmitted wirelessly through the skin from an external, magnetically retained audio processor. Since the external processor does not include a vibrator, the weight is quite low, which reduces the risk of the external device falling off, while increasing wearing comfort since less magnetic force is required for retention. This is the latest and most advanced type of bone conduction concept currently available, and although the surgery is usually straightforward, it may be challenging in some cases to accommodate the implanted part. Since this concept includes implanted electronics, it is under a similarly high level of quality control as a cochlear implant. The surgical complexity and costs for treatment are, however, far lower than for a cochlear implant and closer to that of a bone-anchored hearing aid.

\section{Non-surgical, intraorally attached bone conductor}

A recent attempt to solve the bone-conduction challenge without surgical implantation was the Soundbite bone conductor from Sonitus Medical. This consisted of an inthe-mouth dental vibrator unit that was wirelessly connected to a behind-the-ear device (18). This device was commercially available for a few years but, in spite of significant investments, there were limitations and practical drawbacks, and the company filed for bankruptcy in 2015.

\section{The need for an improved bone conduction solution}

The above background describes some of the previous efforts and shows how difficult it has been to find a simple, straightforward, robust bone conduction concept. The solutions are either not user-friendly or impractical, or they involve surgical implantations with all the increased complexity in such treatment. The enormous efforts and investments behind the above solutions also clearly show the widespread clinical need for good bone conduction solutions.

The need for an efficient user-friendly, non-surgical bone conductor is significant for both children and adults, although in pediatrics there are specific needs.

In children, a fairly rapid hearing rehabilitation period is important since they may, after a fairly short time, lag behind in school or in development since they frequently cannot follow classroom activities or social interactions (19).

In the case of a unilateral conductive loss, the motivation for surgery may often be lower than for a patient with a bilateral conductive loss. However, it is well-documented that children with unilateral hearing losses have significant problems in school (20). In pediatrics, many conductive losses may also have an uncertain duration, and as long as there is hope for recovery, there is usually no implant surgery. The child and/or the parents may also simply want to avoid implant surgery or surgery in general for other reasons. Many people simply want a non-surgical option, and with the drawbacks of the hitherto nonsurgical options, it has, in many cases, meant no device at all or the device ending up in the drawer. In pediatrics and younger adults the conductive losses are, in most cases, pure conductive losses with a normal cochlear function, and so the challenge for a hearing device is principally limited to overcoming the air-bone gap.

Based on the need for a better non-surgical bone conduction solution, the author outlined the concept for an adhesive bone conduction system, which is described below.

\section{The adhesive bone conduction concept}

The adhesive bone conduction concept represents a new type of bone conduction system (21). The core of the new concept is a disposable, adhesive adapter that has, on one 
a)

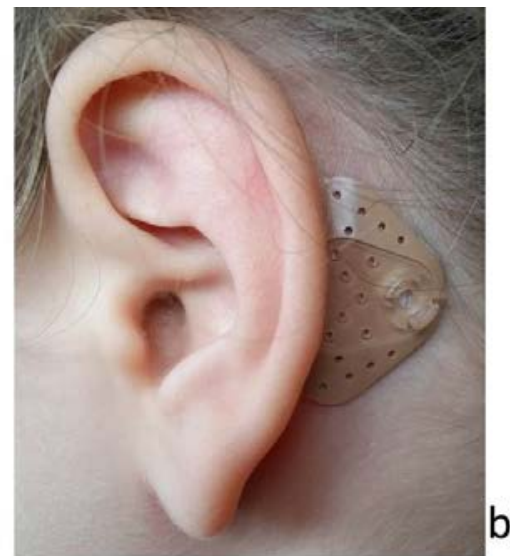

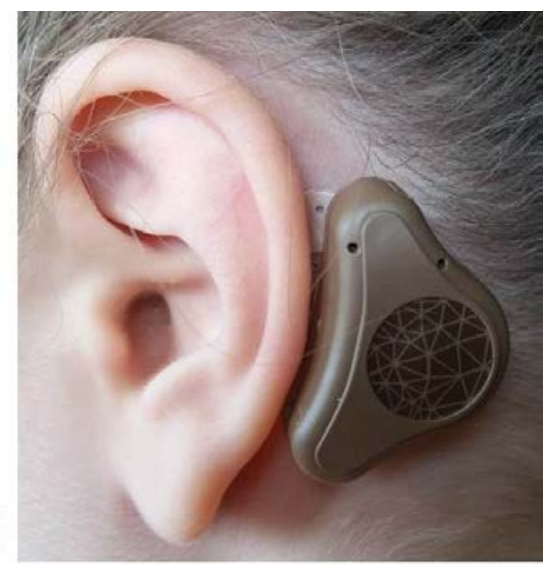

Figure 1. The Adhear adhesive bone conduction system. a) The attached adhesive adapter. b) The audio processor connected to the adhesive adapter. The audio processor can be snapped on and off from the adhesive adapter without removing the adhesive adapter from the skin. The adapter is usually worn for 3-7 days before changing it to a new one. side, an adhesive surface to attach it to the hairless skin behind the pinna and, on the other, a connection to which the audio processor can be easily connected and disconnected (see Fig. 1). By pressing the device at the front end, the audio processor can be taken off the user's head without tearing the adhesive adapter off from the skin. The concept works without any pressure against the skin and offers secure retention without bulky headband arrangements.

\section{The adhesive adapter}

The adhesive adapter is a soft rubber pad with a rigid center plate that has a snap coupling to which the audio processor can be connected. The adhesive adapter is worn day and night and is usually worn for around 3 to 7 days before changing to a new one. This is essential in offering a skin-friendly concept, since the change interval for the adhesive adapter can be optimized to what is suitable for the skin in combination with the adhesive.

The top layer of the skin, the stratum corneum, consists of 15 to 20 layers of dead skin cells, with the cells on top naturally flaking off on a daily basis (22). The renewal rate for stratum corneum in young adults is approximately



Figure 2. Simplified model of bone conduction transmission through the skin from a bone conduction device. M1 is the mass of the skull which is coupled via the skin $\mathrm{k} 1$ to the mass $M 2$ which is primarily the mass of the skin contact plate. The skin contact plate is, via the internal vibrator spring $k 2$, coupled to the oscillating mass $M 3$ of the vibrator. A high mass $M 2$ reduces efficiency of the transmission, and a firmer connection $\mathrm{k} 1$ increases the efficiency of the transmission of the vibrations to the bone of the skull.
20 days (23). An adhesive that is torn off from the skin will remove some top layer skin cells with it, and, if this is done too frequently, skin redness will occur. The Adhear concept offers secure retention, so it requires a welladhering adhesive. Moreover, by not having to tear the adhesive away from the skin each time the audio processor is taken off, this significantly reduces the frequency of adhesive removals from the skin. The entire adhesive adapter is disposable, which offers an easy-to-use and practical concept.

The Adhear adhesive adapter has a medical adhesive that has been designed to interact with the moisture of the skin itself, which is important for interacting with the skin. It is able to both resorb and transport moisture in a way that is suitable for the skin in this application. Furthermore, the adhesive adapter can stay in place while taking a shower or swimming. The change interval of the adhesive adapter is individual, and will vary with sweating, positioning, and mechanical handling. In order to achieve a lasting attachment, it is essential to ensure the skin is dry and hairless over the entire area where the adhesive adapter is placed, and to place it with sufficient pressure.

The mechanical coupling between the audio processor and the adhesive adapter allows the audio processor to be tilted off from the adapter and has been designed so that the wear and tear of the coupling is not located on the audio processor. The elastic snap is instead located on a disposable adhesive adapter that is frequently changed. This is in direct contrast to the design of a coupling for a percutaneous concept, where the plastic snap is located on the audio processor, since the skin-penetrating abutment should not be the part that wears out. The Adhear coupling design is a way of making the audio processor more robust overall. Furthermore, the Adhear system has a low-profile mechanical design to reduce the load on the adhesive and to avoid the device touching the outer ear or collar.

\section{Adhesive bone conduction transmission physics}

A simplified model for bone conduction transmission, which includes transmission of vibrations through the skin, includes a triple-mass mechanical system (see Figure 2). The model includes the mass of the human head (M1) which is coupled through the skin (k1) to the mass 
(M2) of the skin contact plate of the device (the mass M2 also includes the mass of other mechanical components of the device which are rigidly connected to the skin contact plate). The skin (k1) is a spring and damping connection between M1 and M2. The mass M2 is connected via the internal spring $(\mathrm{k} 2)$ of the vibrator to the oscillating mass (M3) of the vibrator. The vibrations are generated by the vibrator's oscillation of the mass M3.

A more firm $\mathrm{k} 1$ connection between M1 and M2 will improve the transmission of vibrations to the skull bone, especially for higher frequencies. A higher weight of the skin contact plate M2 will decrease the transmission of vibrations to the skull bone, especially for higher frequencies. In a conventional bone conductor with pressure against the skin, the mechanical coupling between M2 and M1 is improved by the pressure since M1 and M2 are then more firmly connected to each other. However, for such a device, the fairly high weight of the skin contact plate M2 will reduce the efficiency.

For the new adhesively attached bone conductor, there is no pressure against the skin, and this reduces transmission through the skin. However, for an adhesive system, the loss of energy due to the lack of pressure against the skin may be less than expected, and for the new adhesive bone conduction concept, the mass M2 is significantly lower compared to that of a conventional bone conductor. The new adhesively attached bone conductor may therefore compensate, at least partially, for the loss in transmission due to a lack of pressure by gaining transmission efficiency thanks to a very low M2 weight. To give a hint about the weight difference, the M2 equivalent mass for a typical softband is around 2 to 3 grams and the corresponding M2 mass for the adhesive concept is around 0.6 grams.

Furthermore, the adhesive adapter is positioned right behind the ear and is closer to the cochlea compared to the position of, for example, a softband contact plate, and, especially for higher frequencies, the hearing stimulation from the adhesive concept may be further improved by this more favorable position. BC stimulation at the bone level in different positions can be improved by around 5-20 dB (at the ipsilateral cochlea) at higher frequencies by moving the stimulation point to a position $5 \mathrm{~cm}$ closer to the ear canal (compared to stimulation away from the ear canal) (24). Although this comparison was done with direct bone conduction at the bone surface, it suggests that, due to a more favorable position on the head, an improvement of the output from the adhesive adapter compared to a softband. The softband performance will also suffer from some loss in efficiency due to the hair being caught between the contact knob and the skin.

\section{Electroacoustic measurements}

\section{Method}

The output of the Adhear audio processor was measured using an Interacoustics SKS 10 skull simulator. The aim was to measure the output of the Adhear processor in the same way as the output from a regular bone-anchored hearing aid processor for a percutaneous application is measured. To enable a firm mechanical connection of the audio processor to the skull simulator, a special snap coupling for the skull simulator was developed, since the skull simulator's standard connection is only compatible with couplings for regular bone-anchored hearing aids. An acoustic test chamber Interacoustics TBS 25 together with an Interacoustics Affinity 2.0 was used for electroacoustic testing.

Furthermore, to objectively compare transmission of vibrations from a pressureless adhesive bone-conduction concept with transmission from a softband arrangement that includes pressure, a soft tissue simulation adapter using a $5 \mathrm{~mm}$ silicone cushion (Shore A 25) to the Interacoustics SKS 10 was developed. This adapter allowed, on the same spot of the simulated skin, attachment of either an adhesive adapter or a softband arrangement with stimulation. When measuring with a softband, hair was placed inbetween the softband pressure knob and the simulated skin, since this is the normal situation on a head. To simulate a regular hairstyle, the total thickness of the compressed hair was around $1 \mathrm{~mm}$. No hair was present for measurements with the adhesive adapter. For the comparison, the same Adhear audio processor was used either on the adhesive adapter or with the softband. The contact force from the softband pressure knob against the simulated skin was $3 \mathrm{~N}$, which corresponds to a well-tightened softband attachment on a head.

\section{Results}

The maximum output of the Adhear audio processor is shown in Fig. 3. The maximum output is in the same range or slightly higher than for a regular bone-anchored hearing aid with the same size battery (size 13) when comparing available datasheets for such devices. The Adhear vibrator has a second resonance boost at around 6 to $8 \mathrm{kHz}$ which offers additional output at high mid frequencies; this may offer valuable additional output which somewhat compensates for damping through the skin. This type of additional boost at high mid frequencies is not available from regular bone-anchored hearing aids since these are designed for percutaneous application.

The output from the Adhear audio processor connected to the pressureless adhesive $\mathrm{BC}$ concept, as well as the



Figure 3. The maximum power output in $d B$ re $1 \mu \mathrm{N}$ of the Adhear audio processor at $90 \mathrm{~dB}$ SPL in. The device was directly connected to an Interacoustics SKS10 skull simulator. The audio processor has a high frequency boost which may be valuable in partially compensating for damping through the skin. 


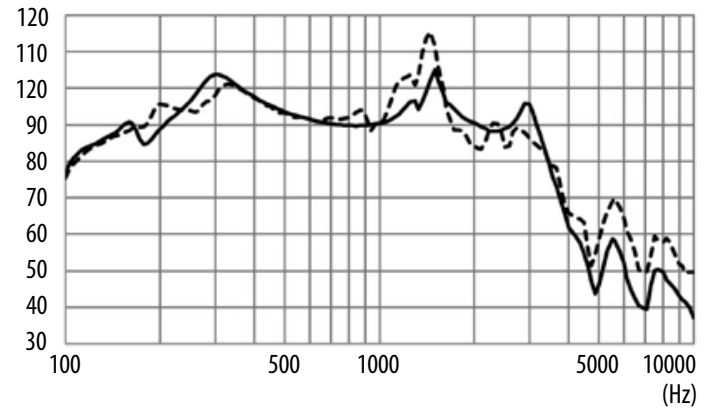

Figure 4. Electroacoustic comparison of the output from the Adhear audio processor attached via the pressureless adhesive concept (solid line) and from the device attached to a pressure-based softband (dotted line) measured using a skin simulating adapter on an SKS 10 skull simulator. The maximum output frequency response is shown in $\mathrm{dB}$ re $1 \mu \mathrm{N}$ and is measured at $90 \mathrm{~dB}$ SPL in. In a clinical situation, the adhesive concept may have additional output at high frequencies due to its more favorable position closer to the ear compared to a softband, and both concepts may have a higher output above $4 \mathrm{kHz}$ due to improved transmission through skin than through the silicone skin simulator.

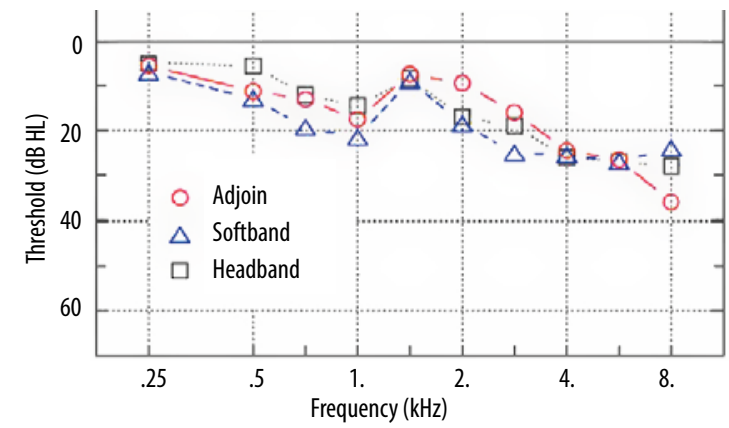

Figure 5. Free-field hearing thresholds for pressureless adhesive bone conduction (Adjoin, circles) vs the same audio processor connected to a conventional softband arrangement (triangles) or to a conventional steelspring headband (squares). Measurements performed on normal hearing subjects with plugged ears $(w=10)$. From (25), with permission.

output from the same processor connected to a conventional pressure based $\mathrm{BC}$ softband concept, are shown in Figure 4 . The stimulation position on the skin simulator was the same for the adhesive adapter as for the softband. Moreover, the output from the adhesive concept is quite similar to the softband at low and mid frequencies up to 4-5 kHz. At higher frequencies, the softband performed slightly better in this laboratory setup. However, on a patient the adhesive adapter would be positioned closer to the ear canal and the hearing organ than the softband knob, and there may be hair inbetween the softband knob and the skin, which may improve the high and mid frequency output from the adhesive concept; so on an actual user the adhesive concept may still be at least equally efficient. The significant drop in output from both concepts at around $4 \mathrm{kHz}$ may be the result of silicone being a compressible material and, for actual skin, this drop may have been even lower since skin primarily consists of water - an incompressible fluid that makes skin a better high-frequency conductor than silicone. The purpose of this comparison was to obtain an objective comparison, although as a simulator for actual bone conduction performance on a patient, it is naturally limited.

\section{Audiometric performance}

The pre-clinical testing of the audiometric performance of the adhesive bone conduction concept compared to the established softband arrangement has been reported in two separate investigations. In the initial 2015 investigation, the new adhesive bone conduction concept was compared to a conventional bone conduction device retained with a softband or steel-spring headband (25). To simulate a conductive hearing loss, normal hearing subjects with ear canals plugged with deeply fitted ear plugs were used for the evaluation $(n=10)$. Free-field hearing thresholds were measured using the same audio processor connected to either the adhesive adapter, a steel-spring headband, or to an elastic softband (Figure 5). The results showed that the performance of the adhesive bone conduction concept is comparable to that of a softband or headband arrangement. This investigation was further confirmed later in 2015 in a similar investigation $(n=20)$ where the adhesive bone conduction concept was compared with a softband retention concept showing equivalent performance for the two concepts (26).

\section{Discussion}

The vision of being able to offer a non-invasive, comfortable, and aesthetically appealing bone-conduction solution for those who are reluctant to have, or who cannot have, implant surgery was the primary impetus for this project.

To develop an easy-to-use, non-invasive ear-level boneconduction concept that works without any pressure against the skin, yet still offers efficient audiological stimulation, has long been seen as impossible and against established principles. The new adhesive bone conductor goes against the common expectation that bone-conduction transmission through the skin requires constant skin pressure. Furthermore, the new concept also goes against the common view among those not involved in skin adhesive science that long-term, repeated adhesion to the skin in the same area results in skin irritation. Both these challenges have been overcome in the new adhesive bone-conduction system. Of course, just as with high quality wound plaster, there is likely to be a few patients with highly sensitive skin who may not tolerate it. However, the skin reactions can be expected to be significantly less troublesome than with many existing bone-conduction solutions which either create problems from constant pressure against the skin, the risk of infections for percutaneous solutions, or the risk of numbness or pain at the site of implantation. The Adhear simply does not require any pressure or need any surgery, which should be beneficial for the skin. A limitation of the Adhear system may be adhesion in cases where the skin behind the ear is very uneven (due to scar tissue) or where there is limited bone support under the skin in this area such as in a case of generous radical mastoidectomy. 
Due to the basic laws of physics, the adhesive bone conduction device does have feedback limitations. Like any ear-level BC device that dampens vibrations through the skin, it does not offer as much amplification, especially in the high frequencies, as a direct bone conduction concept in which the vibrator is directly and firmly connected to the bone of the skull. The adhesive bone conduction system does not replace the implant solution for all patients, but it will nonetheless prove a very valuable and easily accessible solution for many patient groups in need of boneconduction amplification.

The adhesive bone conduction concept offers similar acoustic output to conventionally retained devices, and is primarily intended for the rehabilitation of unilateral and bilateral conductive hearing losses. This is a significant patient group, and in children and young adults almost all conductive hearing losses are pure conductive losses and not mixed hearing losses.

Clinical results with the adhesive bone conduction concept have not yet been published due to the novelty of this technology; however the results presented at scientific conferences as described below indicate that it may be an important clinical treatment option for the relevant patient groups. Several studies presented at conferences are planned for publication in scientific journals.

The first preliminary clinical outcome with the adhesive bone conduction concept came from Birmingham Children's Hospital, UK. At the clinic, 20 children with bilateral or unilateral conductive hearing losses with normal cochlear function were fitted with the adhesive bone conduction concept (27). These patients had not been interested in implant surgery and had previously been fitted with a bone-anchored hearing aid on a softband, which was either in the drawer or worn for a limited time. Dissatisfaction was due to poor wearing comfort, practical drawbacks, or cosmetic issues. The ages ranged from 4 to 14 years and the follow-up time was 3 to 12 months. Of these 20 patients, 19 reported no skin problems at all from the adhesive concept, and only one patient reported minor problems during a shorter period but could still continue to wear it. The audiological performance of the adhesive concept in terms of free-field hearing thresholds was comparable to the performance with the same audio processor connected to a softband. Subjective evaluation using the Glasgow Children's Benefit Inventory score (GCBI) showed that the new adhesive bone conduction concept offered significant value to the patients and was worn with high rates of satisfaction.

The reported conclusions from the study were:

- The adhesive adapters were comfortable and stable with the audio processor

- The audiological outcomes were good even at higher frequencies

- The subjective benefits were excellent

- There were no skin problems

- The device was very well accepted by children and carers. The patients in this study who have now worn it the longest have now used the adhesive bone conduction concept on a daily basis for 4 years, and all the patients in the study were fitted more than 3 years ago. The vast majority of patients have chosen to continue to wear the adhesive bone conduction concept since they were fitted and are continuing to wear the Adhear system (Ann-Louise McDermott, pers. comm.).

Scientific publications on clinical data and on the Adhear are not yet available, and the above experiences are as reported in abstracts and orally at a scientific conference and as presented on slides shared by the presenter. Clinical experiences should therefore be regarded as preliminary.

A further clinical study at the Institute of Physiology and Pathology of Hearing, Warsaw, Poland, included not only a comparison with a softband solution $(n=5)$ but also a comparison between Adhear and a magnetically attached bone conductor (Baha Attract with a Baha 4 processor) $(n=5)$. Compared with the semi-implantable magnetically attached bone conductor, Adhear was found to be acoustically comparable (28).

The Adhear concept has also been investigated as an alternative CROS solution for patients with single-sided deafness (29). Adhear was compared with a conventional air-conduction CROS solution $(n=17)$. The Adhear was found to be useful or better for $66 \%$ of the test candidates, and the conclusion was that Adhear may be a suitable clinical option for this patient group.

Most Adhear candidates will have very similar bone conduction audiograms, i.e. normal cochlear function at all frequencies. Therefore, there is less need for a complex fitting procedure and in its factory setting Adhear is already well adapted to these patients. The device may even be used clinically without any individual frequency shaping or programming; however, there is configuration software available for fine tuning and user adaptation. Of course, advanced pre-processing features such as automatic adaptive directional microphones, noise reduction, etc., are still as relevant as with any other type of hearing aid and are included in the new Adhear processor.

Although the new adhesive bone conductor has proven to be an easy-to-use bone conduction alternative, there is nonetheless still room for further technical developments as well as further clinical investigations.

At the very birth of this innovation, the first listening tests using very simple equipment were not that impressive, and it could all have ended up in the drawer at that point. However, as development progressed, innovative technical solutions and further understanding emerged and challenges were overcome.

During initial development, this project was named Adjoin, and this name was previously used to describe the adhesive bone conduction concept. The adhesive bone conduction system is now a product of Med-El Medical Electronics, Innsbruck, Austria, and the system is being brought to the market under the name Adhear.

\section{Conclusion}

The Adhear adhesive bone conduction system offers comfortable and secure retention of the ear-level audio 
processor without the need for a bulky headband arrangement or surgical implants. The Adhear works without any pressure against the skin and its audiological performance is comparable to the softband arrangement for bone-anchored hearing aids. The output of the Adhear audio processor is optimized for adhesive application and is a new direction compared to regular high-end bone-anchored hearing aid audio processors.

The design of the concept, where the audio processor can be connected and disconnected from the adhesive adapter without tearing the adhesive away from the skin, is a key factor in its success. This design significantly reduces the frequency with which the adhesive has to be removed from the skin, a vital factor.

The audiological performance of the new concept relies on the low weight of the adhesive adapter, improving the mechanical transmission, and on an improved stimulation position closer to the ear canal of the user compared to a softband. The adhesive bone-conduction system should be a valuable clinical alternative for patients with bilateral or unilateral conductive hearing losses. The reported clinical experiences focused on children have indeed been very positive, with excellent results and high patient satisfaction; patients have continued to wear the device on a daily basis for more than 2 years. Scientific publications with clinical data are, at the time of writing (April 2018), not yet available and so the clinical results reported from scientific conferences should be regarded as preliminary. Scientific publications are planned to report these results, as well as several more clinical investigations from clinics around the world.

\section{Acknowledgments}

The author would like to thank Ann-Louise McDermott, Anne Child, Arjan Bosman, and André Sadeghi for their invaluable clinical research contributions during early development, as well as Daniel Barkum for electroacoustic engineering and Madeleine Wångdahl for mechanical design assistance. He also thanks Hamidreza Mojallal for valuable input on content. Ingeborg Hochmair is thanked for recognizing the clinical importance and function of the adhesive bone conduction concept at an early stage, which was fundamental in making the concept available to the benefit of hearing impaired around the world.

\section{Declaration of interest statement}

The author is founder and CEO of the research company Otorix AB, Gothenburg, Sweden.

\section{References}

1. McDermott AL, Dutt SN, Tziambazis E, Reid AP, Proops DW. Disability, handicap and benefit analysis with the bone-anchored hearing aid: the Glasgow hearing aid benefit and difference profiles. J Laryngol Otol Suppl, 2002; 29-36.

2. Tjellstrom A, Granstrom G. Long-term follow-up with the bone-anchored hearing aid: a review of the first 100 patients between 1977 and 1985. Ear Nose Throat J, 1994; 73(2):112-114.

3. Tjellström A, Håkansson B, Granström G. Bone-anchored hearing aids: current status in adults and children. Otolaryngol Clin North Am, 2001; 34: 337-64.

4. Snik AFM, Mylanus EAM, Cremers CWRJ. The bone-anchored hearing aid in patients with a unilateral air-bone gap. Otol Neurotol, 2002; 23: 61-6.

5. Vaneecloo FM, Ruzza I, Hanson JN. The monaural pseudostereophonic hearing aid (Baha) in unilateral total deafness: a study of 29 patients. Rev Laryngol Otol Rhinol (Bord), 2001; 122: 343-350.

6. Bosman AJ, Snik AF, van der Pouw CT, Mylanus EA, Cremers CW. Audiometric evaluation of bilaterally fitted bone anchored hearing aids. Audiology, 2001; 40: 158-167.

7. Westerkull P. Baha: the direct bone conductor. Trends Amplif, 2002; 6 (2), 45-52.

8. Westerkull P. The Ponto bone-anchored hearing system. Advances in Oto-rhino-laryngol, 2011; 71: 32-40.

9. Hol MK, Cremers CW, Coppens-Schellekens W, Snik AF. The Baha Softband. A new treatment for young children with bilateral congenital aural atresia. Int J Pediatr Otorhinolaryngol, 2005; 69(7): 973-80.

10. Verhagen CV, Hol MK, Coppens-Schellekens W, Snik AF, Cremers CW. The Baha Softband. A new treatment for young children with bilateral congenital aural atresia. Int J Pediatr Otorhinolaryngol, 2008; 72, 1455-9.

11. McDermott AL, Sheehan P. Paediatric Baha. Adv Oto-rhinolaryngol, 2011; 71: 56-62.
12. Siegert R. Partially implantable bone conduction hearing aids without a percutaneous abutment (Otomag): technique and preliminary clinical results. Adv Otorhinolaryngol, 2011; 71:41-6.

13. Hol MKS, Nelissen R, Agterberg M, Cremers CW, Snik AF. Comparison between a new implantable transcutaneous bone conductor and percutaneous bone-conduction hearing implant. Otol Neurotol, 2013; 34: 1071-5.

14. Briggs R, Van Hasselt A, Luntz M, Goycoolea M, Wigren S, Weber P, Smeds H, Flynn M, Cowan R. Clinical performance of a new magnetic bone conduction hearing implant system: results from a prospective, multicenter, clinical investigation. Otol Neurotol, 2015; 36: 834-41.

15. Dimitriadis PA, Farr MR, Allam A, Ray J. Three year experience with the Cochlear Baha Attract implant: a systematic review of the literature. BMC Ear Nose Throat Disord, 2016; 16: 12.

16. Sprinzl G, Lenarz T, Ernst A, Hagen R, Wolf-Magele A, Mojallal H, Todt I, Mlynski R, Wolframm MD. First European multicenter results with a new transcutaneous bone conduction hearing implant system: short-term safety and efficacy. Otol Neurotol, 2013; 34(6): 1076-83.

17. Gerdes T, Salcher RB, Schwab B, Lenarz T, Maier H. Comparison of audiological results between a transcutaneous and a percutaneous bone conduction instrument in conductive hearing loss. Otol Neurotol, 2016; 37(6): 685-91.

18. Popelka GR, Derebery J, Blevins NH, Murray M, Moore BC, Sweetow RW, Wu B, Katsis M. Preliminary evaluation of a novel bone-conduction device for single sided deafness. Otol Neurol, 2010; 31(3): 492-497.

19. Tomlin D, Rance G. Long-term hearing deficits after childhood middle ear disease. Ear Hear, 2014 Nov-Dec; 35(6): e233-42.

20. Brookhouser PE, Worthington DW, Kelly WJ. Unilateral hearing loss in children. Laryngoscope, 1991; 101(12 part 1): 1264-72.

21. Westerkull P. Bone conduction hearing aid system. United States patent 9,154,887 B2, 2015. 
22. Zhen YX, Suetake T, Tagami H. Number of cell layers of the stratum corneum in normal skin: relationship to the anatomical location on the body, age, sex and physical parameters. Arch Dermatol Res, 1999; 291: 555-9.

23. Grove G, Kligman A. Age associated changes in human epidermal cell renewal. J Gerontol, 1983; 38: 137-42.

24. Håkansson B, Reinfeldt S, Eeg-Olofsson M, Ostli P, Taghavi H, Adler J, Gabrielsson J, Stenfelt S, Granström G. A novel bone conduction implant (BCI): engineering aspects and pre-clinical studies. Int J Audiol, 2010; 49: 203-15.

25. Bosman AJ, Snik AF, Mylanus EAM, Hol MKS. Evaluating the efficacy of the Adjoin plaster. Poster at $5^{\text {th }}$ International Congress on Bone Conduction Hearing and Related Technologies, 2015.

26. Kittelfors M, Mattson E. Subjective and objective comparison between two bone conductor hearing system, Softband and Adjoin. Research project AUD 620 at the University of Gothenburg, Sahlgren Academy, Institute of Neuroscience and Physiology, Unit of Audiology, 2015.
27. McDermott AL, Child A, Gill J. The Adjoin adhesive adapter: new innovation in bone conduction hearing. $5^{\text {th }}$ International Congress on Bone Conduction Hearing and Related Technologies, Lake Louise, Canada, 2015. (Video record).

28. Skarzynski PH, Olszewski L, Ratuszniak A, Osinska K, Krol B. Audiological evaluation of the novel bone conduction hearing device Adhear in experienced users of an existing transcutaneous bone anchored hearing device. $6^{\text {th }}$ International Congress on Bone Conduction Hearing and Related Technologies, Nijmegen, The Netherlands, 2017.

29. Mertens GG, Bouzegta R, Van de Heyning P. User satisfaction and clinical efficacy of a new non-invasive bone conduction hearing system in single-sided deafness. $13^{\text {th }}$ Congress of the European Federation of Audiology Societies, Interlaken, Switzerland, 2017. 
